\title{
Real Estate Development at Landslides
}

\author{
Hakan Kaya ${ }^{1, *}$, Cem Gazioğlu ${ }^{2,3}$ \\ ${ }^{1}$ Beylikdüzü Municipality, BEYLIKKDÜZÜ, ISTANBUL-TR \\ ${ }^{2}$ Istanbul University, Institute of Marine Sciences and Management, Department of Marine Environment, BERKARDA \\ Remote Sensing and GIS Laboratory, 34134 VEFA, FATIH, ISTANBUL-TR \\ ${ }^{3}$ Istanbul University, Faculty of Open and Distance Education, Associate Degree Program of GIS FATIH, ISTANBUL-TR
}

\begin{abstract}
The desire to grow and develop at a fast pace without regard for scientific conditions is an obsession, particularly of developing countries like Turkey. However, any development achieved in ignorance of the scientific process and sustainability leads to higher costs as well as serious losses in terms of human and other life.

Our area of study is one of the best examples of the negative effects of this type of development. The area under study covers the landslide sites located on the southwest of Istanbul (the Büyükçekmece, Beylikdüzü, Avcilar and Esenyurt districts) which is the largest city in Turkey. In this study, we tried to probe into the real estate development process of the landslide sites, the measures taken or failed to be taken in this process, the humanitarian and economic conditions involved and the things required to be done.
\end{abstract}

Keywords: Landslide, Büyükçekmece, Küçükçekmece, Beylikdüzü, Avcılar, Esenyurt.

\section{Introduction}

Landslides occur with an extreme catastrophic natural disaster and habitually lead to humanity. Risk assessment for landslides in densely populated urban areas is currently one of the most important disaster justification tasks all over the world (Sassa et al. 2004). Landslides cause major disasters on a global scale and the frequency of their occurrence seems to be on the rise. The main causes for the observed intensification in landslide disasters are a greater susceptibility of surface soil to instability as a result of overexploitation of world resources and deforestation, and greater vulnerability of the exposed population as a result of growing urbanization (Nadim et al., 2006).

Study area the area remaining between Büyükçekmece lake (BL) and Küçükçekmece lake (KL) and it is a district in the European side of İstanbul in Marmara region, is surrounded by Çatalca in the $\mathrm{N}$ and $\mathrm{W}, \mathrm{KL}$ in the E, the Marmara Sea in the S (Fig.1). In this area the eastern hillsides of BL, the hillsides of Devebagirtan Valley, the hillsides on the coasts of Beylikdüzü district, the eastern and western hillsides of Kavaklı Creek that splits Beylikdüzü District in the middle as it springs out from the north and spills into the Marmara Sea to the south, the eastern and western hillsides of Haramidere, the valley hillsides making up the branches of this creek, the hillsides of Avcrlar district facing the sea, Esenyurt district located to the north of the area under study, and the hillsides of the valleys located in the Çakmaklı and Kıraç areas are where the landslides are observed quite frequently (Ertek et al., 2001). In the light of latest investigation of faults exist as preparative parameter for the landslides between BL and KL. Also, the vertical erosion process during the last glacial age should have been effective in the occurrence of the landslides. Additionally, the existence of resistant fissured clay with watertight sand interlayers and the erosion processes on the heel of the slopes are determined as extra effective preparative factors (Dalgı̣c et al., 2010). 


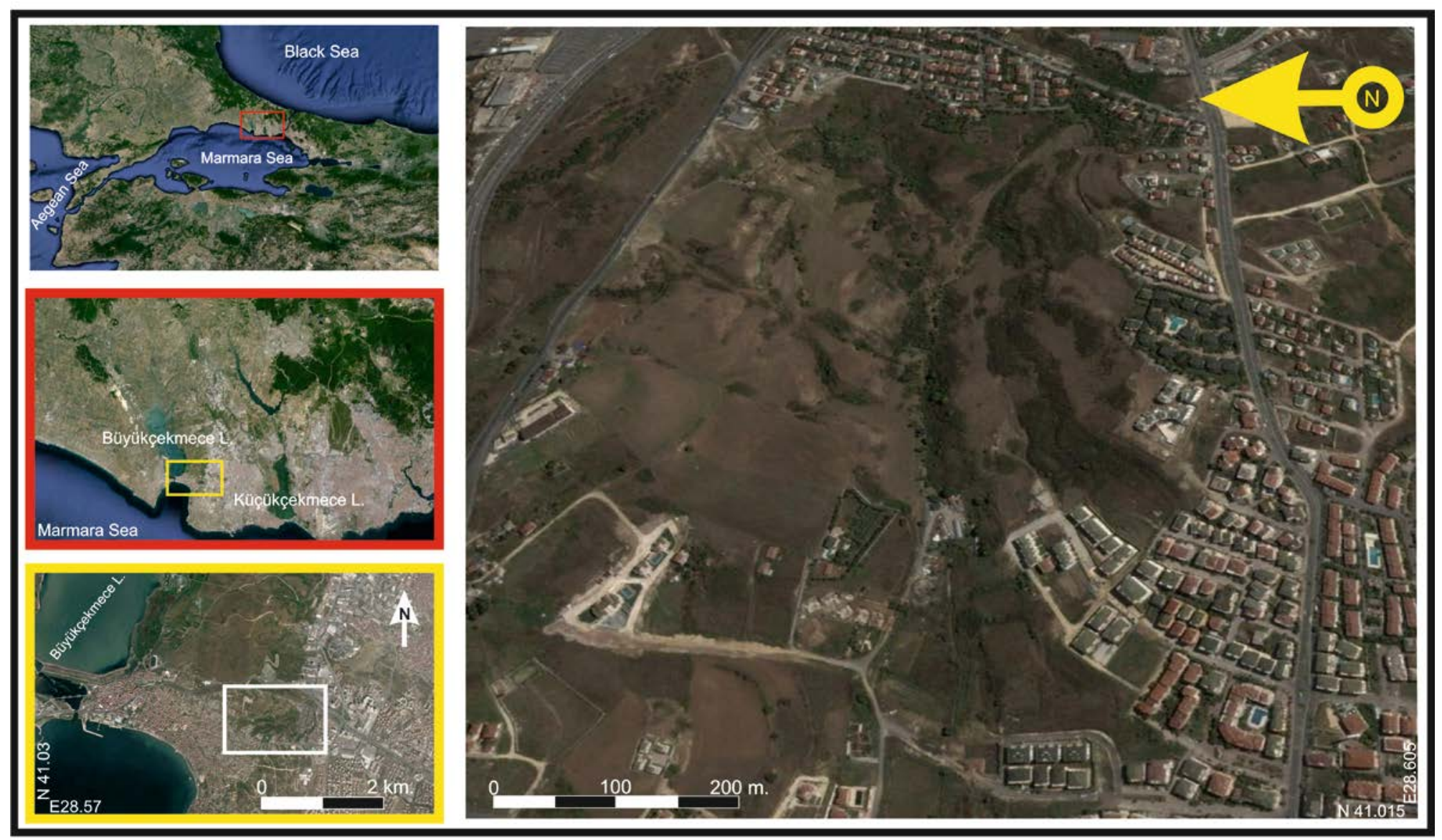

Fig 1. Study Area and Landslides of study area and Devebağırtan Valley 
Many different triggers cause landslides which are rainfall, earthquakes and snow melting (Guzzetti, 2002).

This manuscript focuses on the assessment of the value of different measures based on land planning that may be approved to notice landslide frequency and related risk at study area which is where the landslides are widespread and unfortunately between the ones that the population and settlements increase the most. The fast pace of population increase in Turkey along with the increase in the number of the settlements are the first and foremost factors that affect Istanbul. The fact that central Istanbul, in other words the old parts of Istanbul, is not suitable for new settlements as well as the astronomic increases in the building prices in this part of the city, have rendered the areas under study attractive in terms of settlements in line with the growth being experienced

The favorable climate has played an important role in the site of study becoming a center of attraction and the increase in demand for the site along with the fact that it lies on the line connecting Asia and Europe and the ease of transportation to central Istanbul, and the favorable building prices have rendered this area even more attractive where settlements are concerned. Due to the foregoing reasons, the demand for this area has increased in line with the increase in population. In parallel to the increase in demand, this area has furthermore experienced fast development. However, the earthquake and landslide sites that threaten the area have not been taken into consideration.

Although the area of consideration had once been subject to damages due to earthquakes and landslides, the pressure applied by the ever increasing population and the high return on investment has led to unplanned development in the area continuing. Even today, measures against landslides are not taken as required and the senseless settlements continue to be erected.

\section{Geologic, Geomorphologic and Geophysical Properties}

Oligocene aged Gürpınar formation composed of clay-claystone and sand levels is located at the bottom. Ergene formation composed of mainly sandy levels overly Gürpınar formation. Moderate stiff-very stiff clay levels become dominant for the upper levels of Ergene formation. Bakırköy formation, which includes limestone as dominant lithology, overly this sedimentary levels (Fig.2).

This formation is suited between 150 to $400 \mathrm{~m}$ thick clays. It develops landslides and flows in places with steep topography. This formation extends from BL and has high water content. The Gürpınar formation is the dominant outcropping in Büyükçekmece region. This formation is fairly young age which is older than 30 million years old. (IMM, 2014).

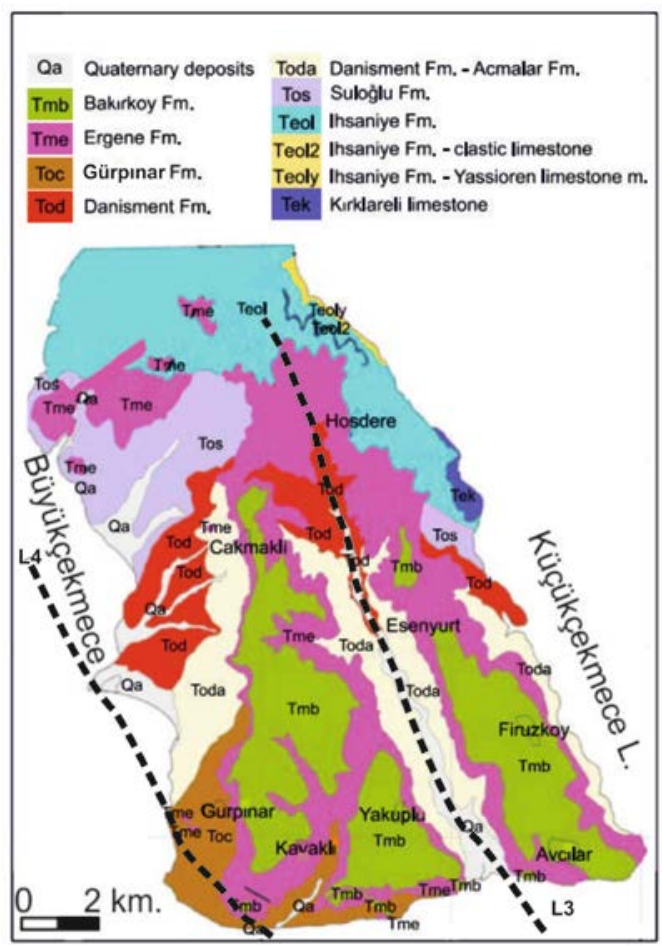

Fig.2. Geology of study area (modified from Doğan et al., 2013; Duman et al., 2006 and Gökaşan et al., 2002)

The bottom layer of the site under study fashions rock formations that do not display metamorphosis of the Paleozoic - Mesozoic age. The tectonics and accumulation that has taken place over time have led to the formation of different lithologies in various properties on the bottom layer in question. We have observed that the majority of the landslides occurring at the study site happen on formations containing 
interim layers of clay stone, sandstone, loam and albarium with high water bearing capacity belonging to the Miocene age.

The thickness of these formations ranges between 10 to 100 meters depending on the location. The determination of the thickness correctly carries great importance in terms of the improvements to be performed in these areas.

The landslide activity on the eastern hillsides of BL, on the hillsides of Devebagirtan Valley as well as Kavaklı Creek and Haramidere valley, on the steep hillsides of Beylikdüzü and Avcılar districts facing the sea can be observed to be both static and active. Furthermore, as can be understood especially from undersea bathymetry maps and the dives performed, the landslides also take place under the sea on the coasts of Beylikdüzü and Avcılar.

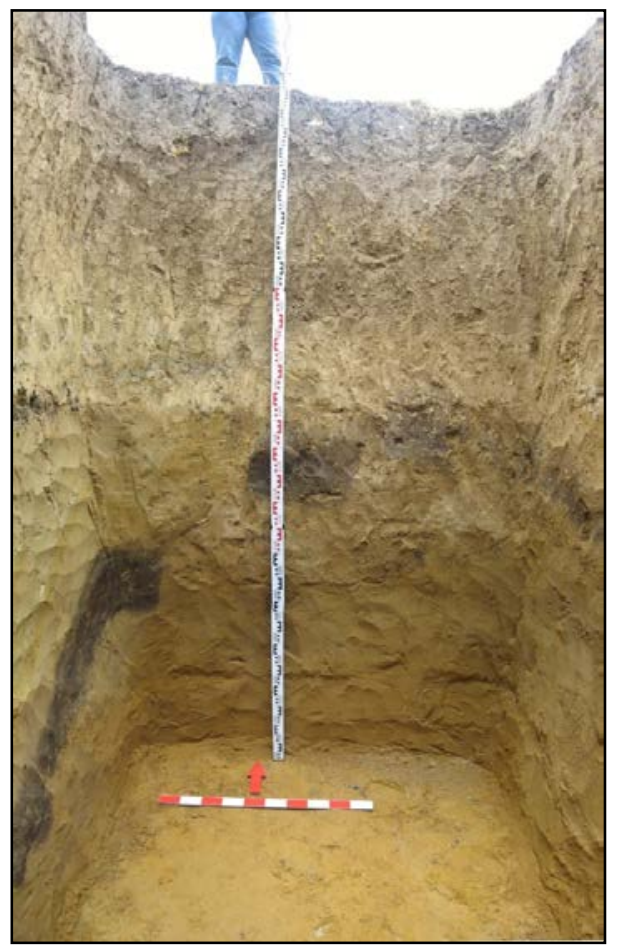

Fig 3. The Fault Line discovered in Bathonea Antique city tothe west of KL.

Study area is located on the North Anatolia Fault Zone (NAFZ), which is one of the most active and important sources of earthquakes in World. It is a known fact that previously, historically significant earthquakes of more than level 7 on the scale took place on this fault line and that the project site has been affected in destructive manner by these earthquakes.

The latest studies conducted led to the expectations of a magnitude $\leq 7$ earthquake to take place again on this fault line, immediately to the south of the same. Moreover it is believed that further fault lines lie in the continental area outside NAF (Algan et al., 2011).

During the studies conducted on Bathonea Antique city to the west of $\mathrm{KL}$, the team conducting the diggings observed landslides in the archeological trench excavated for research purposes (Fig.3.). This shows that continental fault lines would be discovered if the area where the landslides have been observed is seriously scanned. When all the foregoing information is taken into consideration it can be seen that a high intensity earthquake would trigger the landslides in the site of the study that has the liquefaction of the ground, and a landslide together with an earthquake would Table 1. Population of Study area

\begin{tabular}{lll}
\hline Settlement & 2007 & 2013 \\
\hline Avcılar & 323,596 & 407,240 \\
Beylikdüzü & 209,675 & 244,760 \\
Büyükçekmece & 137,606 & 211,000 \\
Esenyurt & 316,377 & 624,733 \\
Total & 987,254 & $1,487,733$ \\
\hline
\end{tabular}

cause even more damage.

\section{Processes Related to Humans}

Population and number of density of population (persons $/ \mathrm{km}^{2}$ ) in the districts of Büyükçekmece, Beylikdüzü, Avcılar, Esenyurt, which are located in the study site, we can see why the real estate developments grow at a fast pace in this area.

Table 1.Population Data published by the Turkish Statistics Institute (TÜIK) between the years 2007-2013 (the reason for taking the data for the years between 2007-2013 as the basis is the fact that the address based population registry system has become applicable as of 2007 in Turkey and that data after this date is 
more accurate in comparison to the data collected before the change. Moreover, in obtaining the population data for the year 2007, the new population data was collated in consideration of the neighborhoods that left the site of study or merged with others in the site in 2009. As such it has been possible to make a comparison according to the district border

Table 2. The surface areas reflect area of the land and are obtained from the data provided by Istanbul Metropolitan Municipality.

\begin{tabular}{llll}
\hline Settlement & $\begin{array}{l}\text { Area } \\
\mathrm{km}^{2}\end{array}$ & $\begin{array}{l}\text { Person/ } / \mathrm{km}^{2} \\
(2007)\end{array}$ & $\begin{array}{l}\text { Person } / \mathrm{km}^{2} \\
(2013)\end{array}$ \\
\hline Avcılar & 42.01 & 7,702 & 9,693 \\
Beylikdüzü & 37.78 & 5,549 & 6,478 \\
Büyükçekmece & 139.17 & 988 & 1,516 \\
Esenyurt & 43.13 & 7,335 & 14,484 \\
Total & 262.09 & 21,574 & 32,171 \\
\hline
\end{tabular}

presently applicable.)

The population at the site of study increases at a rate much faster than the population increase of Istanbul as can be understood from Tables 1 and 2 above. The real estate developments have also picked up pace in parallel to the increase in the rate of population.

When the population data pertaining to the previous years is examined, it can be seen that increases in population slowed until the 1990s; however, due to the high growth experienced in the Turkish economy during that time, and a decrease in the availability of sites within Istanbul, and as a consequence steep price hikes at the sites, our site of study was suddenly rendered an area of interest. The area has become the focus of attention for, in particular, retirees, domestic migrants, and lower and middle income families.

Consequently, after the 1990s, real estate developments in the area started cropping up at a very fast pace. However, interestingly, the shanty settlements, which are observed frequently in the areas that are developed fast in Turkey and Istanbul, have not been observed in a widespread manner in the area under study.
Nevertheless, similar to the other areas under development in Turkey, the high-rise buildings have been erected without any regard to the risk of earthquakes and landslides in spite of the fact that the ground is not eligible for this type of buildings.

Between 1990 and 2005, many settlements and buildings erected on the hillsides of the Devebağırtan valley (Fig.4-5), Yakuplu and Haramidere valley (Fig 6), Avc1lar (Siteler Ambarlı area), Kavaklı (Fig 7) and the Gürpınar-Çakmaklı line that are prone to landslides have been damaged as a result of this phenomenon, and while some of them collapsed others were reinforced to help them survive (Yücel et al., 1998).

According to Demirci et al. (2009), highly risk of landslide area is about $25 \%$ of total study area, moderate one is approximately $36 \%$. Latest settlements are mostly situated highly and moderate potential of landslide. As a result of the damages caused by landslides, the developments in such areas decreased in number to a great extent. In the aftermath of these incidents, the increasing population of the area chose to settle in high-rises built on higher but relatively stronger ground instead of the landslide prone hillsides located in our area of study. However, the full occupation of the buildings on higher plateaus and the increase in their values, led the hillsides to again become the focus of attention, after being ignored since 2005 , regardless of the landslide risks involved. Study area under the tsunami risk (Alpar, et al., 2004). Unfortunately, it is now possible to witness the developments being erected especially on the Gürpınar - Çakmaklı line, in theDevebağırtan and Haramidere valleys, Yakuplu andthe Kavaklı landslide area. In spite of the fact that laws and regulations have been put into force to ensure that the buildings erected in the aftermath of the 1999 Izmit earthquake were resistant against this phenomenon, the effects of landslides have been disregarded in all the regulatory arrangements. Although the buildings erected the second time in the landslide areas have been successful in terms of the construction techniques applied, they were nevertheless still vulnerable to landslides due to the lack of engineering measures taken against the prevention of landslides, inadequacy of the piles used, and suspension of these piles at a very far distance from the plane of landslides. It is clear that the buildings that have not yet succumbed to the effects of landslides would do so in the long term. 


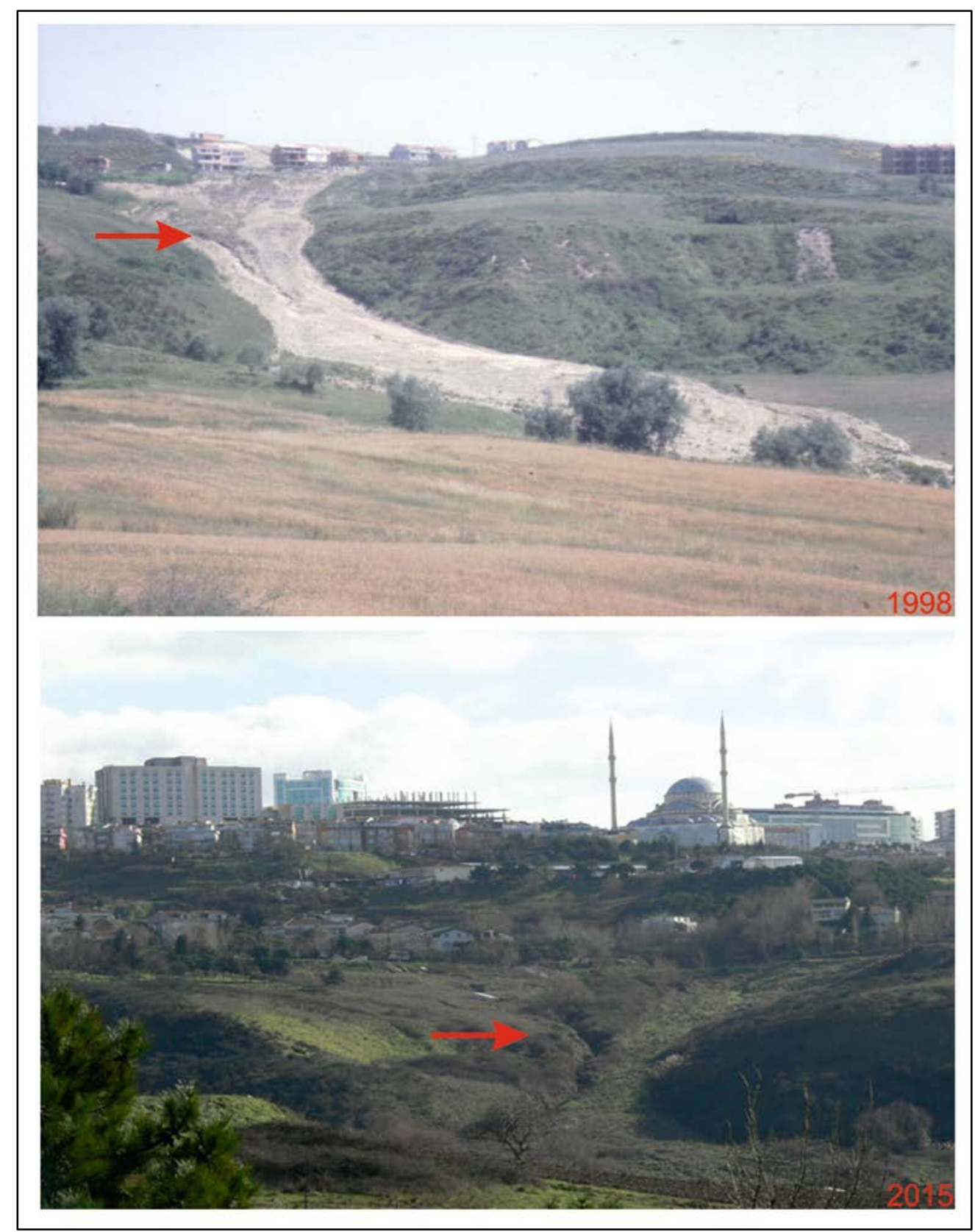

Fig 4. Landslides is suited in Devebağırtan valley SE (Büyükçekmece 1998-2015) 


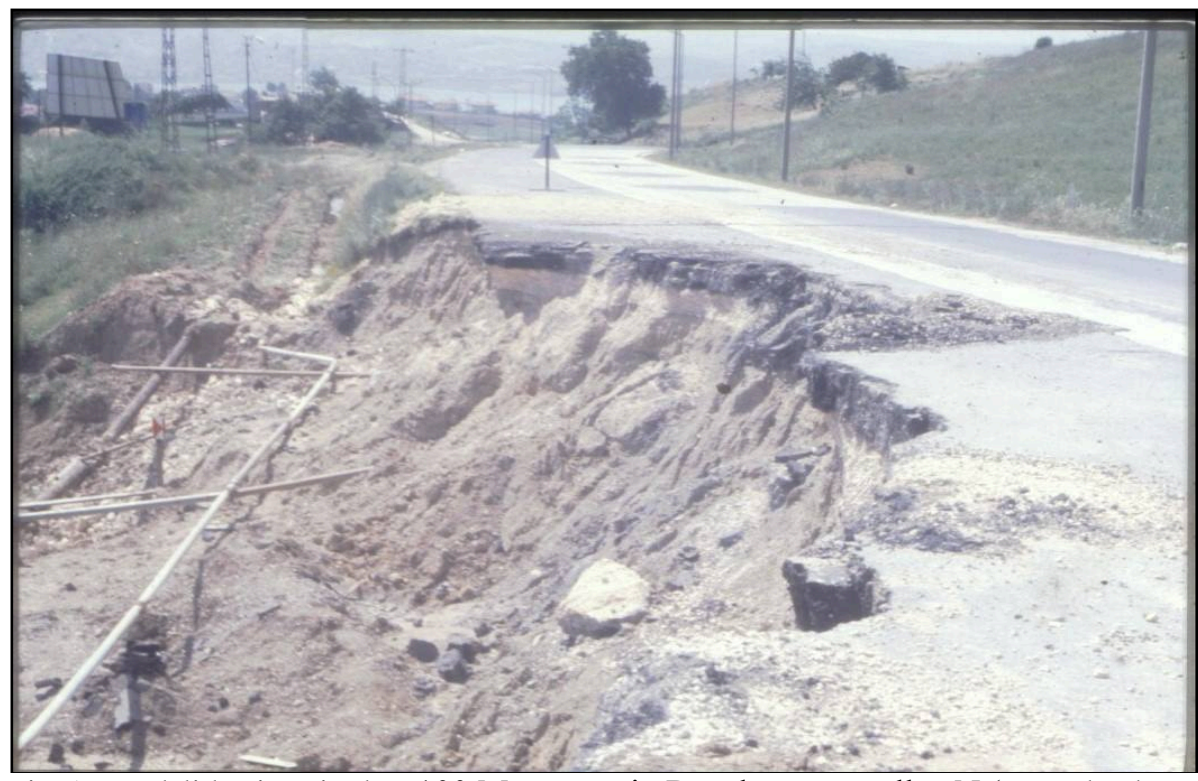

Fig 5. Landslides is suited D-100 Motorway in Devebağırtan valley N ( Büyükçekmece 1998)

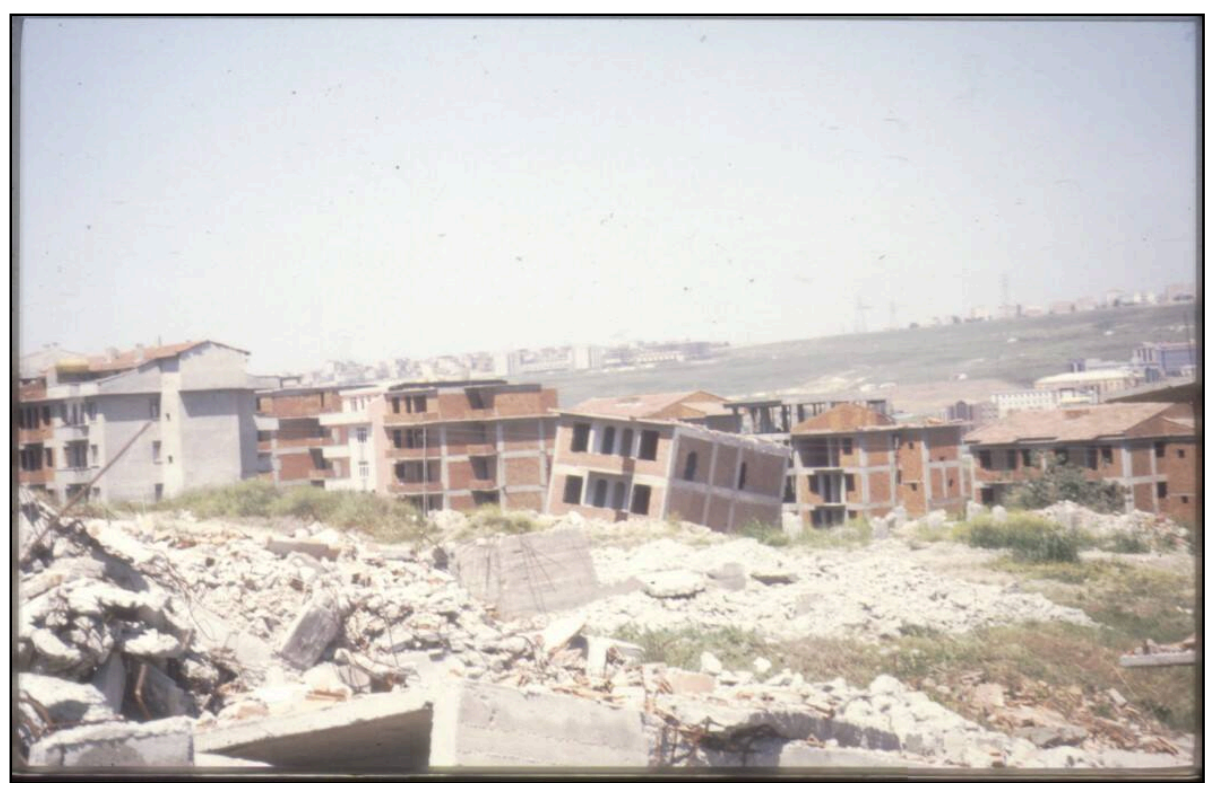

Fig 6. Damage of landslides of W part of Haramidere Valley (Yakuplu-1998) 


\section{Conclusion and Recommendations}

Presently, at the site of study there are no measures being taken to prevent landslides other than the dysfunctional piles used. Leaving aside implementing precautionary measures, the landslides are completely disregarded and the real estate developments are going ahead, in most of the cases, as if the problem did not exist. In this respect the measures indicated below in regards to the area must be implemented immediately.

Landslide vulnerability zonation is very necessary with a view to define the under danger areas of landslides. More than a few approaches have been suggested for landslide affects. Remote sensing and GIS techniques could be cheapest and fastest methods and they wolud be useful for data acquisition, processing and analysis. Any landslide hazard or risk assessment must begin with the collection of information on where landslides are located. This is the goal of landslide mapping. Detailed and multitemporal landslide map of the area must be prepared. Additionaly the relationships between the lithological and structural settings and the landslide types and pattern must be prepated.

The most significant output of the validation of the landslides susceptibility models is that the best model was generated by using elevation, geology, land use factors. Additionally, the evaluation of the estimate power of the variables recommends that the earlier ground clarifications about connecting factors were biased.

Records of each landslide-triggering event, covering the entire territory affected by the event must be invastigated.. The areas subject to landslides must be classified according to the risk involved. Preventative measures must be taken in the light of this classification. Use frequency-size statistics to describe landslides triggered by extreme events. Study the spatial relationships between failures of different ages and types.

The described landslides are characteristically suited in the lithologies including the penetrable sandstone layers and resistant layers such as claystone, siltstone and mudstone layers. Considering this finding, it is possible to say that one of the main conditioning factors of the landslides in the study area is lithology. An another factor governing the landslides is the sandstone bedding planes and their orientations. It must be kept in mind that $\mathrm{Mg}>7$ earthquakes, expected to take place at a distance of approximately $15 \mathrm{~km}$ to the NAF, would trigger the landslides in the sensetive area and consequently the effects could be felt more in these areas.

If possible the landslide prone areas that have not yet been developed should be excluded from the scope of zoning. This may also ensure that the areas with dense population will have a chance to settle down.

At the areas of landslides, the engineering measures oriented to the prevention of this phenomenon must be immediately started in line with the landslide map. This will ensure that buildings in these areas are rendered more secure. If the safety of these buildings cannot be improved, the ones in high risk areas must be moved to less riskier sites and the high risk areas should be converted into recreational sites. Although it has been observed that pile reinforcements have not been installed in many buildings in the area, especially with the effects of the law and regulations that were put into force after the 1999 Izmit earthquake, it has also been observed that preliminary ground studies are being conducted and pile supports are enforced in some landslides.

However, the use of the ground analysis conducted is quite doubtful. The inspection we conducted revealed that the ground studies performed in the area are in fact all copies of each other. For this reason the recommended pile heights were inadequate in many places.

The ground analysis must not only address the issue of earthquakes but also take into account the landslides. If included within the scope of Engineering Measures; A good drainage network to quickly remove the water accumulating in the area must be established.

Load or pile placement to balance the pressure and load on the upper part of the plane must be performed on the heel of the landslide plane. 
At steeply inclined places the hillsides must be protected (steel panels, planting of trees, covering with stone or concrete walls, etc. Reducing the inclination of and scaling the ground. Hardening the ground texture (cementing, use of chemicals, filling, curing and application of similar methods). If possible the loads, pressure and vibration on the landslide plane must be reduced. The measures indicated above, and similar, must be put into application after landslide classification of the area is completed. Otherwise it would not be possible to prevent serious losses and damages that may occur in the future in this area.

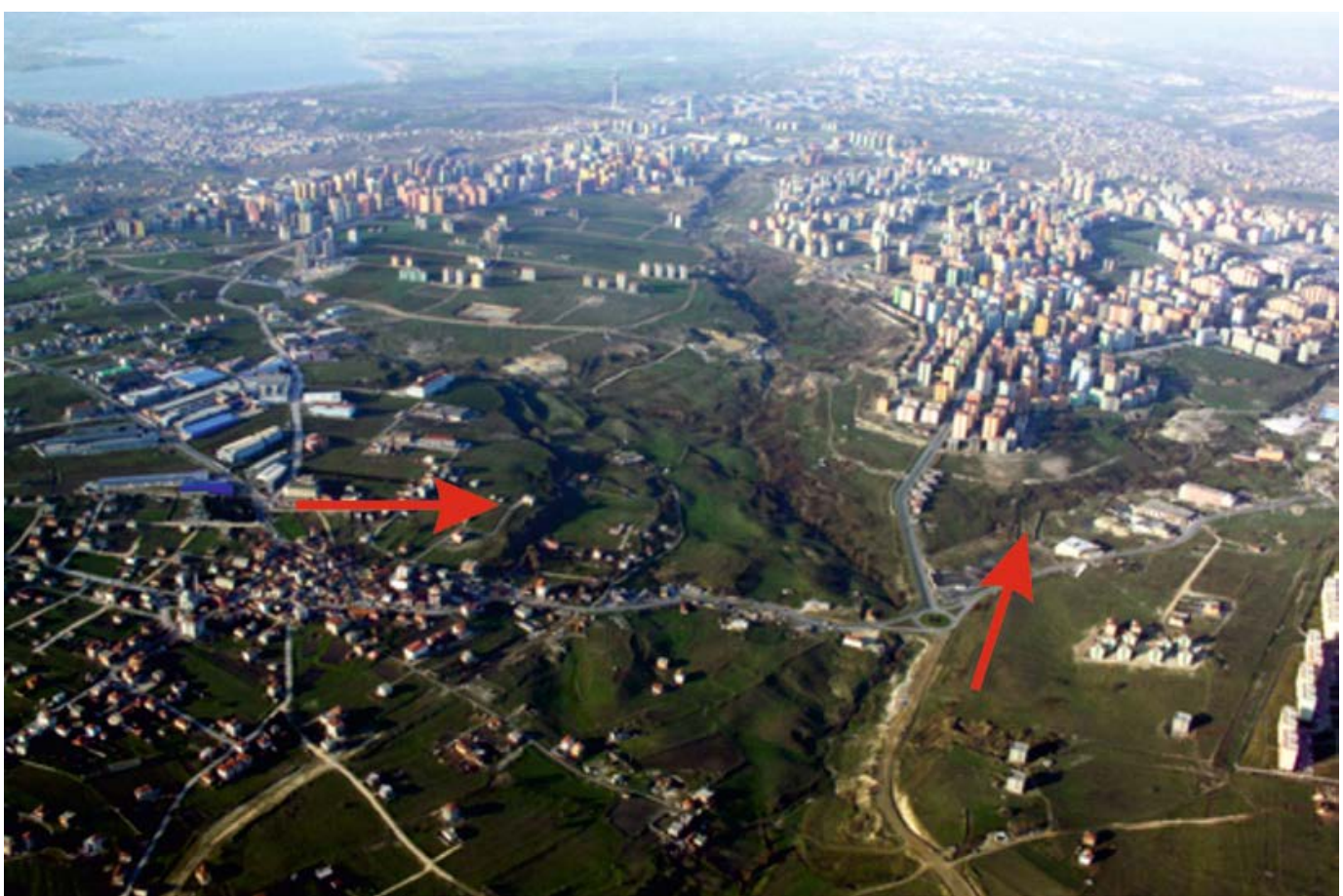

Fig 7. Landslides situated on Kavaklıdere valley (Beylikdüzü) and its branches.

\section{References}

Algan, O., Yalçın, m.N., Özdoğna, M., Yı1șmaz, Y., Sarı, E., Elams, E., Yılmaz, İ., Bulkan, Ö., Ongan, D., Gazioğlu, C., Nazik, A., Polat, M.A. and Meriç, E. (2011). Holocene coastal change in the ancient harbor of Yenikap1-İstanbul and its impact on cultural history. Quaternary Research, Vol. 76 (1):30-45.

Alpar, B., Gazioğlu, C., Altınok, Y., Yücel, Z.Y., and Dengiz, Ş. (2004). Tsunami hazard assessment in Istanbul using by high resolution satellite data (Ikonos) and DTM, XXth Congress of the ISPRS, Istanbul, 1223 July 2004.

Ambraseys N.N. (2002). The seismic activity of the Marmara Sea Region over the last 2000 years. Bull. Seism. Soc. Am., 92, pp 1-18.
Ambraseys N.N. ve Finkel, C.F. (1991). Longterm seismicity of Istanbul and of the Marmara Sea region. Terra nova 3. 527539.

Dalgıç, S. Turgut, M and Kuşku, İ. (2010). The Evaluation of Preparative and Triggering Parameters on Occurrence of Landslides in the Büyükçekmece - Küçükçekmece, Uygulamall Yerbilimleri Say1:2, 56-73.

Demirci, A., Karajuyu, M. İncekara, S and Karaburun, A. (2009). Evaluating the Urbanization Process in Gurpinar in Terms of Construction-related Activities Within Landslide Risk Areas, Doğu Coğrafya Dergisi, Vol 14, Issue 21, pp.95-108.

Doğan, U., Öz, D. and Ergintav, S. (2013) Kinematics of landslide estimated by repeated GPS measurements in the Avcilar region of Istanbul, Turkey, Studia 
Geophysica et Geodaetica, Vol. 57, Issue 2, pp 217-232.

Duman T.Y., Can T., Gokceoglu C., Nefeslioglu H.A. and Sonmez H., 2006. Application of logistic regression for landslide susceptibility zoning of Cekmece Area, Istanbul, Turkey. Environ. Geol., 51, 241-256.

Duman, T.Y., Keçer, M., Ateş, Ş., Emre, Ö., Gedik, İ., Karakaya, F., Durmaz, S., Olgun, Ş., Şahin, H., Gökmenoğlu, O. (2004). İstanbul metropolü batısındaki (Küçükçekmece - Silivri - Çatalca yöresi) kentsel gelişme alanlarının yer bilim verileri. M.T.A. Genel Müdürlüğü, Ankara.

Ertek T.A., Akgün H., Gazioğlu C., Yücel Z.Y., Kaya H., "Repeatedly With An Anthropogenic Triggering Example Of The Büyükçekmece Landslides: Çakmakli Landslide (Istanbul, Nw Turkey)", 5th International Conference on Geomorphology, England, 23-28 Ağustos 2001, pp.23-28.

Gökaşan E., Gazioğlu C., Alpar Ş.B., Yücel Z.Y., Ersoy Ş., Gündoğdu O., Yaltirak C., Doğan H.E. (2002) "Evidences Of Nw Extension Of The North Anatolian Fault Zone In Marmara Sea; A New Approach To The 17th August 1999 Marmara Sea Earthquake", Geo Marine Letters, vol.21, pp.183-199.

Guzzetti, F (2002). Landslide Hazard Assessment And Risk Evaluation: Limits and Prospectives, Mediterranean Storms (Proceedings of the 4th EGS Plinius Conference held at Mallorca, Spain, October 2002).

IMM. Surface areas of Istanbul's districts. http://www.ibb.gov.tr (02.12.2014).

Kaya, H., Yücel, Z.Y., Doğan, E and Gazioğlu, C. (2008). "İstanbul'un Marmara Denizi Kıyılarında Heyelan Riski” Türkiye' nin Kiy1 ve Deniz Alanları VII. Ulusal konferans1, Türkiye Kiyıları 08 Konferans Bildirileri Kitabı, p. 986,997, 27-30 May 2008, Ankara.

Nadim, F., Kjekstad, O., Peduzzi, P., Herold, C and Jaedicke (2006). Global landslide and avalanche hotspots, Landslides, Vol 3(2), pp.159-173.

Sassa K, Wang GH, Fukuoka H, Wang FW, Ochiai T, Sugiyama M, Sekiguchi T (2004) Landslide risk evaluation and hazard zoning for rapid and long-travel landslides in urban development areas. Landslides 1:221-235

TÜİK. Address based Population Registration System Data. Turkish Statistics Institute, http://tuikapp.tuik.gov.tr/adnksdagitapp/adn ks.zul Date obtained: 02.12.2014.

Uzun, Y. and Kaya, H. (2012). İstanbul'un Gülen Yüzü (Happy Face of Istanbul) Beylikdüzü. Pelikan Basım, İstanbul.

Yücel Z.Y., Gazioğlu C., Doğan H.E., Kaya H. (1998) "Küçükçekmece- Büyükçekmece Gölleri Arasındaki Kıyı Kullanımının, Uzaktan Algilama Teknolojileri ile İrdelenmesi", Kay 98, 22-25 Eylül, Ankara, Türkiye, 